\title{
BRAND PERSONALITY TOWARD ATTITUDE AND BEHAVIORAL INTENTIONS VIA BRAND PERSONALITY APPEAL ON GRABBIKE
}

\author{
DESI LESTARINI \\ AULIA DANIBRATA \\ Trisakti School of Management, Jl. Kyai Tapa No. 20 Jakarta 11440, Indonesia \\ auliadanibrata@yahoo.com
}

\begin{abstract}
The first purpose of this study is to investigate whether each of brand personality dimension variables has a direct influence to brand personality appeal or not. The second purpose is to demonstrate the utility of brand personality appeal as a mediator as if each brand personality dimension variables has an indirect significant impact towards attitude and behavioral intentions through brand personality appeal in the context of online ride hailing service brand. Data used obtained from direct distribution questionnaires to 140 respondents. Statistical analysis was conducted using SMARTPLS 2.0. Research findings can be summarized as follows. First, Responsibility, Activity, and Aggressiveness Brand Personality has a direct influence and statistically significant in order to predict Brand Personality Appeal. Second, Responsibility, Activity, and Aggressiveness Brand Personality actually has a similar indirect influence and statistically significant in order to predict Attitude and Behavioral Intentions via Brand Personality Appeal.
\end{abstract}

Keywords: Brand personality, brand personality appeal, attitude, behavioral intentions

\begin{abstract}
Abstrak: Tujuan pertama penelitian adalah untuk mengetahui ada tidaknya pengaruh secara langsun masing masing dimensi dari variable Brand Personality terhadap Brand Personality Appeal. Tujuan kedua dari penelitian adalah untuk menjelaskan pemanfaatan Brand Personality Appeal sebagai mediator dari masing masing dimensi Brand Personality yang memiliki signifikansi dampak tidak langsung terhadap Attitde dan Behavioral Intentions dalam konteks merk jasa Online Ride Hailing. Data diperoleh dari pembagian kuesioner langsung pada 140 responden. Analisa statsitik dioleh menggunakan SMARTPLS 2.0. Hasil dari penelitian dapat disimpulkan sebagai berikut: pertama; Responsibility, Activity, dan Aggressiveness Brand Personality memiliki pengaruh secara langsung secara signifikan untuk memprediksi Brand Personality Appeal. Kedua; Responsibility, Activity, dan Aggressiveness Brand Personality memiliki kemiripan dalam pengaruhnya secara tidak langsung terhadap Attitude dan Behavioral Intention melalui Brand Personality Appeal.
\end{abstract}

Keywords: Brand personality, brand personality appeal, attitude, behavioral intentions 


\section{INTRODUCTION}

Until the second quarter of 2017, the Indonesian economy grew 5,01 percent from the second quarter of 2016. Looking at the trend of GDP growth rate for the last five years, arguably the economic situation of Indonesia has not returned to its peak as in the second quarter of 2013. However, the current situation also still can be considered a quite good because the growth is still above the figure of five percent.

The growth occurred in Gross Domestic Product was actually determined by seventeen industries which make significant contribution to it. Inferring from the average rate of growth during the same time on the second quarter of 2013, 2014, 2015, 2016, and 2017 which are coincides load same Eid festive period in Indonesia, researchers compared the average growth rate of seventeenth in that last five years.

On this occasion, the research tried to highlight two industries striking on the top five with the best growth rates. The first attempt was "Information and communication" which has the highest average growth rate over the last five year (10,318 percent) and second one is the fifth place industry "Transportasi dan Pergudangan" or also called Transportation and Logistics (7,346 percent) which is in details, this industry was the number one with the highest index number of implicit Gross Domestic Product at the second quarter of 2017. It does means the growth rate of the gross domestic product of Indonesia in second quarter of 2017 was also highly affected by the value increasing from transportation and logistics industry.

What makes these two industries are interesting are because of their strong attachment to each other. One of the best reasons underlying the high growth of transportation and logistics industry in Indonesia is the utilization of advanced technology, so company can be increasing the efficiency and effectiveness of business processes with the result that reach higher productivity. Lovelock
(2011: 211) said, "Service redesign process can be successfully realized by the changes in technology, customer needs, added service features, and new offerings that made existing processes crack and creak." So, it is not a surprise, revitalization process that has become outdated can be happen especially in the field of transportation and logistics industry which in the last five years has a good growth rate.

This research would focus on the third subsector with the highest average growth rate, land transportation. Looking on the fact, one of the most important features in land transportation is motor vehicles, because overall increasing number of the motor vehicle characterizes the development of land transportation subsector. According to Transportation Statistics report by Badan Pusat Statistika Indonesia, they summarize that land transportation shows the increasing demand for transportation facilities which is also in line with the increase in population, mobility, and people's activity specifically more than the other subsectors (Badan Pusat Statistika Indonesia 2015: 21).

The development of land transportation in DKI Jakarta can be seen from the state of population or other related indicators with this means of transportation, including the number of motor vehicles, number of passengers and goods transported trains, and road conditions that pass by means of land transportation (Badan Pusat Statistik Provinsi DKI Jakarta 2016: 13).

The high mobility of people and goods in the capital has not been matched by availability of safe and convenient public transport. This causes usage growth of private motor vehicles from year to year increase very rapidly and not proportional for the infrastructure current condition. A large population with increasing purchasing power leads to growth ownership of motor vehicles is quite high. This condition is exacerbated by additional hundreds of thousand vehicles outside Jakarta moving in Jakarta every 
day, while effort for build additional roads and other infrastructures often faces constraints.

Then, there is Grab, one of the best online ride hailing and logistics services companies in Indonesia in the last three years. Grab application that has an alternative solution for land transportation utilizes the advanced technology especially the community behavior on internet and smartphone usage.

Therefore, in details the research is actually needed to understand fully how the actual use and application service thinking with contemporary theories of branding in the various services and their influence on consumer attitudes and behavior patterns in repetition. Heretofore, the relationship between brand personality and brand personality appeal has not been tested in any marketing context including services and social marketing. Concluding that, actually this is also the first aim of the study (Gordon et al. 2016).

The second aim of the study was to investigate whether brand personality appeal acted as a mediator linking brand personality with attitude and behaviors (Gordon et al. 2016) to addresses the gaps in theoretical understanding of the relationship between brand personality and brand personality appeal identified by Freling et al. (2011) as the predecessor journal from Gordon et al. (2016).

Furthermore, in the fact, there are multitude of brands in the marketplace from a diverse range of goods and service sectors that offer opportunity to add more research on brand personality and brand personality appeal. Further research examining service brands from an international or global perspective also likely to yield valuable insight (Gordon et al. 2016).

Table 1 Problem between Variables

\begin{tabular}{|c|c|c|}
\hline Variables & Literature & Result \\
\hline $\begin{array}{l}\text { Brand } \\
\text { Personality > } \\
\text { Brand } \\
\text { Personality } \\
\text { Appeal }\end{array}$ & $\begin{array}{l}\text { Freling, T.H., Crosno, J.L. and } \\
\text { Henard, D.H. (2011), "Brand } \\
\text { personality appeal: } \\
\text { conceptualization and empirical } \\
\text { validation", Journal of the Academy } \\
\text { of Marketing Science, Vol. } 39 \text { No. 3, } \\
\text { pp. 392-406. }\end{array}$ & $\begin{array}{l}\text { only theoretical statement, had not empirically } \\
\text { tested }\end{array}$ \\
\hline Variables & Literature & Result \\
\hline
\end{tabular}

Gordon et al., (2016), "Unlocking the potential of branding in social marketing services: Utilising brand personality and brand personality appeal", Journal of Service Marketing, Vol. 30 (1) 48-62.
Gordon et al (2016) did empirical test to fulfill the theoretical gap by Freling et al (2011) and got significant result for responsibility $>B P A$, activity $>$ BPA, and emotionality $>$ BPA

Brand
Personality >
Brand
Personality
Appeal >
Attitude

Gordon et al., (2016), "Unlocking the potential of branding in social marketing services: Utilising brand personality and brand personality appeal", Jpurnal of Service Marketing, Vol. 30 (1) 48-62
Significant but only empirically tested for health and banking services at Australian brand. Brand Personality and Brand Personality Appeal can positively influence consumer attitudes and behavioral intentions in both social marketing service, and commercial marketing service context; but it only tested on health and banking serviced and had not tested on any other type of services. Specifically the brand personality dimensions influenced on them are 


\begin{tabular}{ll}
\hline Brand & responsibility, activity, and aggressiveness. It \\
Personality $>$ & $\begin{array}{l}\text { might be has different results with the other type } \\
\text { of services. }\end{array}$ \\
Brand & \\
Personality & \\
Appeal $>$ & \\
Behavioral & \\
Intentions & \\
\hline
\end{tabular}

Table Source: Own-self Processed

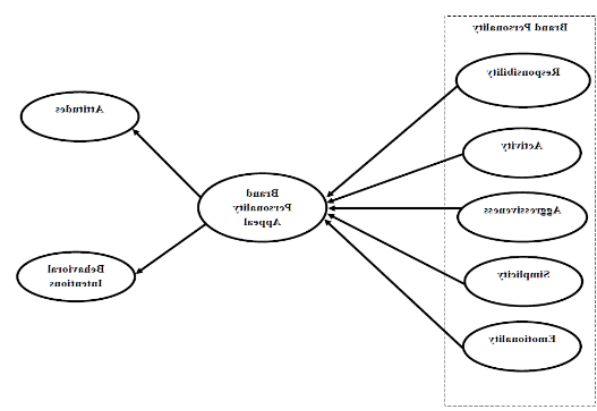

Figure 1 Theoretical Research Model

\section{Hypothesis}

$\mathrm{H}_{1} \quad$ There is a significant influence of responsibility brand personality to brand personality appeal

$\mathrm{H}_{2} \quad$ There is a significant influence of activity brand personality to brand personality appeal

$\mathrm{H}_{3} \quad$ There is a significant influence of aggressiveness brand personality to brand personality appeal

$\mathrm{H}_{4} \quad$ There is a significant influence of simplicity brand personality to brand personality appeal

$\mathrm{H}_{5} \quad$ There is a significant influence of emotionality brand personality to brand personality appeal

$\mathrm{H}_{6} \quad$ There is a significant influence of responsibility brand personality to consumer attitude via brand personality appeal

$\mathrm{H}_{7} \quad$ There is a significant influence of activity brand personality to consumer attitude via brand personality appeal

$\mathrm{H}_{8} \quad$ There is a significant influence of aggressiveness brand personality to consumer attitude via brand personality appeal

$\mathrm{H}_{9} \quad$ There is a significant influence of simplicity brand personality to consumer attitude via brand personality appeal

$\mathrm{H}_{10} \quad$ There is a significant influence of emotionality brand personality to consumer attitude via brand personality appeal

$\mathrm{H}_{11} \quad$ There is a significant influence of responsibility brand personality to consumer behavioral intentions via brand personality appeal

$\mathrm{H}_{12}$ There is a significant influence of activity brand personality to consumer behavioral intentions via brand personality appeal

$\mathrm{H}_{13} \quad$ There is a significant influence of aggressiveness brand personality to consumer behavioral intentions via brand personality appeal

$\mathrm{H}_{14} \quad$ There is a significant influence of simplicity brand personality to consumer behavioral intentions via brand personality appeal

$\mathrm{H}_{15} \quad$ There is a significant influence of emotionality brand personality to consumer behavioral intentions via brand personality appeal

\section{RESEARCH METHOD}

Sampling technique used by this research is non probability sampling type judgmental sampling defined by Malhotra (2015: 379). This non probability sampling relies on the 
personal judgment of the researcher rather than chance to select sample elements. The researcher can arbitrarily or consciously decide what elements to include in the sample.

Criteria used for this research are: (1) all males and females above 17 years old (minimum 18 years old) who have Grab app on their smartphone. (2) focused mobility on West Jakarta; include people who depart from West Jakarta (e.g. live in West Jakarta) and who arrive in West Jakarta (e.g. work at the office at West Jakarta) regularly. (3) Have used GrabBike service thrice or more. (4) Has Grab-Pay that supports the Grab app.

In order to elicit the quantitative data, the questionnaires directly distributed to the respondents and taken back when they have finished filling them out, or we ask their answer for the questions and we fill the questionnaire in responsibility of them. This research used the offline method, obtained on multiple days at September 2017.

Departing from the concept of brand personality and following the definitions given by the experts, hence a brand personality is defined as a consumer's perception of the human personality traits attributed to a product or service (Hardjanti 2011). The scale consists of five dimensions, and result total of 12 personality traits for the product. Responsibility can be defined as a personality dimension when brand have a good understanding to be reliable and trustworthy responsible both towards themselves and towards its customers, employees, and or the environment. Activity can be defined as a personality dimension when brand is comprehensively communicating their object message or experience which can implies a heightened collaboration between the subject to the world of objects, which is means consumer and the marketing entity. Aggressiveness can be defined as a brand personality dimension which is born from a set of acts involving the use of indirect means; kind of idealistic, optimistic, and sentimental efforts, then use that to achieve goals. Simplicity is a brand personality dimension which is reflects singleness, kind of easiness thus it has a tendency to reduce appeal. Emotionality means a personality that can build affective bonds between consumers and the brand itself via expressed emotional, romantic, and sentimental that loading high on it. Referring the concept of brand personality appeal and following the definitions given by the experts, hence a brand personality appeal is defined as the brand ability to appealing its personality in front of their consumers. The dimension of brand personality appeal represented by sixteen item. According from the concepts and following the definitions given by the experts, attitude is defined as a predisposition or a tendency to respond positively or negatively towards a certain idea, object, person, or situation, and responses to challenges, incentives, and rewards (together called stimuli). The stimuli can be varying and impact consumers in different ways. Build upon the concepts and following the definitions given by the experts, behavioral intentions can define as state likelihood to return for purchase the product or service and recommended it to the others in the future.

In this research, the scale used is itemizes rating scale Likert. According to Malhotra (2015: 368) Likert scale is "a widely used rating scale that requires the respondents to indicate the degree of agreement or disagreement with each of a series of statements about the stimulus objects". Typically, each scale item has five response ategories, ranging from "strongly disagree" to "strongly agree". 
Table 3 Variable Operationalization

\begin{tabular}{|c|c|c|c|c|}
\hline Variable & Category & Dimension & Indicator & Scale \\
\hline \multirow[t]{10}{*}{$\begin{array}{c}\text { Brand } \\
\text { Personality }\end{array}$} & $\begin{array}{l}1 \text { until } 5 \\
1 \text { until } 5 \\
1 \text { until } 5\end{array}$ & Responsibility & $\begin{array}{l}\text { the brand is down to earth } \\
\text { the brand is stable } \\
\text { the brand is responsible }\end{array}$ & $\begin{array}{l}\text { Likert } \\
\text { Likert } \\
\text { Likert }\end{array}$ \\
\hline & 1 until 5 & \multirow[t]{3}{*}{ Activity } & the brand is active & Likert \\
\hline & 1 until 5 & & the brand is dynamic & Likert \\
\hline & 1 until 5 & & the brand is innovative & Likert \\
\hline & 1 until 5 & \multirow[t]{2}{*}{ Aggressiveness } & the brand is aggressive & Likert \\
\hline & 1 until 5 & & the brand is bold & Likert \\
\hline & 1 until 5 & \multirow[t]{2}{*}{ Simplicity } & the brand is ordinary & Likert \\
\hline & 1 until 5 & & the brand is simple & Likert \\
\hline & 1 until 5 & \multirow[t]{2}{*}{ Emotionality } & the brand sentimental & Likert \\
\hline & 1 until 5 & & the brand is romantic & Likert \\
\hline Variable & Category & Dimension & Indicator & Scale \\
\hline Brand & 1 until 5 & & this brand's personality is satisfactory & Likert \\
\hline Personality & 1 until 5 & & this brand's personality is pleasant & Likert \\
\hline \multirow[t]{14}{*}{ Appeal } & 1 until 5 & & this brand's personality is attractive & Likert \\
\hline & 1 until 5 & & this brand's personality is positive & Likert \\
\hline & 1 until 5 & & this brand's personality is bad & Likert \\
\hline & 1 until 5 & & this brand's personality is poor & Likert \\
\hline & 1 until 5 & & this brand's personality is undesireable & Likert \\
\hline & 1 until 5 & & this brand's personality is common & Likert \\
\hline & 1 until 5 & & this brand's personality is ordinary & Likert \\
\hline & 1 until 5 & & this brand's personality is predictable & Likert \\
\hline & 1 until 5 & & This brand's personality is routine & Likert \\
\hline & 1 until 5 & & this brand personality is apparent & Likert \\
\hline & 1 until 5 & & this brand's personality is distinct & Likert \\
\hline & 1 until 5 & & this brand's personality is obvious & Likert \\
\hline & 1 until 5 & & this brand's personality is vague & Likert \\
\hline & 1 until 5 & & this brand's personality is unclear & Likert \\
\hline Variable & Category & Dimension & Indicator & Scale \\
\hline Attitudes & 1 untill 5 & & I like GrabBike & Likert \\
\hline
\end{tabular}




\begin{tabular}{|c|c|c|c|}
\hline & $\begin{array}{l}1 \text { untill } 5 \\
1 \text { untill } 5 \\
1 \text { untill } 5\end{array}$ & $\begin{array}{l}\text { I react favourably to GrabBike } \\
\text { I feel positive toward GrabBike } \\
\text { GrabBike is good }\end{array}$ & $\begin{array}{l}\text { Likert } \\
\text { Likert } \\
\text { Likert }\end{array}$ \\
\hline \multirow{7}{*}{$\begin{array}{l}\text { Behavioral } \\
\text { Intentions }\end{array}$} & 1 until 5 & $\begin{array}{l}\text { If I had to have use ride-hailing platform } \\
\text { again, I would want to use GrabBike }\end{array}$ & Likert \\
\hline & 1 until 5 & $\begin{array}{l}\text { I would highly recommend GrabBike to } \\
\text { other people }\end{array}$ & Likert \\
\hline & 1 until 5 & $\begin{array}{l}\text { I have said positive things about GrabBike } \\
\text { to my family and friends }\end{array}$ & Likert \\
\hline & 1 until 5 & I intend to continue having GrabBike & Likert \\
\hline & 1 until 5 & I have no desire to change service providers & Likert \\
\hline & 1 until 5 & $\begin{array}{l}\text { I intend to follow the GrabBike advice given } \\
\text { to me }\end{array}$ & Likert \\
\hline & 1 until 5 & $\begin{array}{l}\text { I am glad I have my ride-hailing service with } \\
\text { GrabBike rather than someone else }\end{array}$ & Likert \\
\hline
\end{tabular}

Data Source: Gordon et al. (2016)

\section{RESULT}

The findings will be explained in two general part; Measurement Model and Structural Model. The measurement model of this study assessed through the composite reliability, convergent validity, and discriminant validity. Two things are important when assessing the PLS-SEM result for the structural model assessed through significance and the relevance of coefficients.

Table 4 Composite Reliability

\begin{tabular}{lccc}
\hline & Construct & Composite Reliability & Result \\
\hline RES & Responsibility & 0,8477 & Reliable \\
ACT & Activity & 0,9178 & Reliable \\
AGR & Aggressiveness & 0,8645 & Reliable \\
SIM & Simplicity & 0,7415 & Reliable \\
EMO & Emotionality & 0,9236 & Reliable \\
BPA & Brand Personality Appeal & 0,9614 & Reliable \\
ATI & Attitude & 0,9242 & Reliable \\
BIN & Behavioral Intentions & 0,9602 & Reliable \\
\hline & Source: Own-self processed using SMARTPLS 2.0 &
\end{tabular}

Table 5 Outer Loading

\begin{tabular}{ccccc}
\hline Indicator & Construct & Factor Loading & Result & t-statistic \\
\hline RES1 & Responsibility & 0,7219 & Valid & 6,2916 \\
RES2 & & 0,8093 & Valid & 17,7044 \\
RES3 & & 0,8819 & Valid & 40,9082 \\
\hline ACT1 & Activity & 0,9074 & Valid & 45,2566 \\
ACT2 & & 0,8784 & Valid & 26,8069 \\
\hline
\end{tabular}




\begin{tabular}{|c|c|c|c|c|}
\hline АCT3 & & 0,8773 & Valid & 25,9733 \\
\hline AGR1 & Aggressiveness & 0,888 & Valid & 26,4551 \\
\hline AGR2 & & 0,8569 & Valid & 17,1042 \\
\hline SIM1 & Simplicity & 0,9866 & Valid & 11,2394 \\
\hline SIM2 & & 0,503 & Valid & 2,2955 \\
\hline EM01 & Emotionality & 0,9271 & Valid & 23,6992 \\
\hline EMO2 & & 0,9254 & Valid & 18,188 \\
\hline BPA1 & Brand Personality Appeal & 0,6233 & Valid & 10,1516 \\
\hline BPA2 & & 0,7807 & Valid & 15,5599 \\
\hline BPA3 & & 0,8268 & Valid & 18,3896 \\
\hline BPA4 & & 0,8407 & Valid & 28,7931 \\
\hline BPA5 & & 0,8341 & Valid & 21,2546 \\
\hline Indicator & Construct & Factor Loading & Result & t-statistic \\
\hline BPA6 & & 0,7947 & Valid & 21,4466 \\
\hline BPA7 & & 0,8039 & Valid & 22,2538 \\
\hline BPA8 & & 0,7781 & Valid & 18,0085 \\
\hline BPA9 & & 0,7794 & Valid & 15,5603 \\
\hline BPA10 & & 0,6881 & Valid & 10,9106 \\
\hline BPA11 & & 0,746 & Valid & 13,0034 \\
\hline BPA12 & & 0,818 & Valid & 25,3588 \\
\hline BPA13 & & 0,8247 & Valid & 34,6958 \\
\hline BPA14 & & 0,7957 & Valid & 25,6329 \\
\hline BPA15 & & 0,7908 & Valid & 17,3199 \\
\hline BPA16 & & 0,7408 & Valid & 13,3882 \\
\hline ATI1 & Attitude & 0,8561 & Valid & 20,9905 \\
\hline ATI2 & & 0,8803 & Valid & 27,3443 \\
\hline ATI3 & & 0,8548 & Valid & 25,7817 \\
\hline ATI4 & & 0,8797 & Valid & 24,5474 \\
\hline BIN1 & Behavioral Intentions & 0,9021 & Valid & 46,2015 \\
\hline BIN2 & & 0,889 & Valid & 43,1795 \\
\hline BIN3 & & 0,8516 & Valid & 34,9351 \\
\hline BIN4 & & 0,8913 & Valid & 42,6421 \\
\hline BIN5 & & 0,9169 & Valid & 68,211 \\
\hline BIN6 & & 0,8056 & Valid & 16,8853 \\
\hline BIN7 & & 0,9021 & Valid & 59,4399 \\
\hline
\end{tabular}

Source: Own-self processed using SMARTPLS 2.0

Table 6 Average Variance Extracted

\begin{tabular}{cccc}
\hline & Construct & AVE & Result \\
\hline RES & Responsibility & 0,6513 & Recommended \\
ACT & Activity & 0,7882 & Recommended \\
GR & Aggressiveness & 0,7615 & Recommended \\
SIM & Simplicity & 0,6132 & Recommended \\
EMO & Emotionality & 0,858 & Recommended \\
BPA & Brand Personality Appeal & 0,6101 & Recommended \\
ATI & Attitude & 0,7531 & Recommended \\
BIN & Behavioral Intentions & 0,7753 & Recommended \\
\hline \multicolumn{4}{c}{ Source: Own-self processed using SMARTPLS 2.0 }
\end{tabular}


Table 7 Latent Variable Correlations

\begin{tabular}{ccccccccc}
\hline & ACT & AGR & ATI & BIN & BPA & EMO & RES & SIM \\
\hline ACT & 1 & 0 & 0 & 0 & 0 & 0 & 0 & 0 \\
AGR & 0,718 & 1 & 0 & 0 & 0 & 0 & 0 & 0 \\
ATI & 0,741 & 0,6253 & 1 & 0 & 0 & 0 & 0 & 0 \\
BIN & 0,5725 & 0,5903 & 0,7764 & 1 & 0 & 0 & 0 & 0 \\
BPA & 0,7614 & 0,7015 & 0,8789 & 0,8472 & 1 & 0 & 0 & 0 \\
EMO & 0,1964 & 0,1969 & 0,2292 & 0,1826 & 0,2465 & 1 & 0 & 0 \\
RES & 0,8068 & 0,6552 & 0,8163 & 0,699 & 0,7991 & 0,2082 & 1 & 0 \\
SIM & $-0,3831$ & $-0,1916$ & $-0,3106$ & $-0,2041$ & $-0,3385$ & 0,0312 & $-0,3502$ & 1 \\
\hline
\end{tabular}

Source: Own-self processed using SMARTPLS 2.0

Table 8 Root AVE

\begin{tabular}{ccc}
\hline Construct & Root AVE & Result \\
\hline Responsibility & 0,8070 & Greater \\
Activity & 0,8878 & Greater \\
Aggressiveness & 0,8726 & Greater \\
Simplicity & 0,7831 & Greater \\
Emotionality & 0,9263 & Greater \\
Brand Personality Appeal & 0,7811 & Greater \\
Attitude & 0,8678 & Greater \\
Behavioral Intentions & 0,8805 & Greater \\
\hline
\end{tabular}

Source: Own-self processed using SMARTPLS 2.0

Table $9 \mathrm{R}$ Square

\begin{tabular}{lc}
\hline & $\mathbf{R}^{2}$ \\
\hline Brand Personality Appeal & 0,7129 \\
Attitude & 0,7725 \\
Behavioral Intentions & 0,7177 \\
\hline
\end{tabular}

Source: Own-self Processed using SMARTPLS 2.0

Table $10 Q$ Square

\begin{tabular}{cc}
\hline & $1-$ SSE/SSO \\
\hline Brand Personality Appeal & $0,1424>0$ \\
Attitudes & $0,5754>0$ \\
Behavioral Intentions & $0,5485>0$ \\
\hline Source: Own-Self processed using SMARTPLS 2.0
\end{tabular}


Table 11 Summary of the Structural Model: Brand Personality to Brand Personality Appeal

\begin{tabular}{|c|c|c|c|c|c|}
\hline Hypothesis & Path & $\begin{array}{c}\text { Original } \\
\text { Sample (0) }\end{array}$ & $\begin{array}{l}\text { T Statistics } \\
\text { (IO/STERR) }\end{array}$ & Result & Supported \\
\hline $\mathrm{H}_{1}$ & $\begin{array}{l}\text { Responsibility } \rightarrow \text { Brand } \\
\text { Personality Appeal }\end{array}$ & 0,4568 & 6,8265 & $\begin{array}{l}\text { Significant direct and } \\
\text { positive path coefficient }\end{array}$ & Yes \\
\hline $\mathrm{H}_{2}$ & $\begin{array}{l}\text { Activity } \rightarrow \text { Brand } \\
\text { Personality Appeal }\end{array}$ & 0,1736 & 2,0969 & $\begin{array}{l}\text { Significant direct and } \\
\text { positive path coefficient }\end{array}$ & Yes \\
\hline $\mathrm{H}_{3}$ & $\begin{array}{l}\text { Aggressiveness } \rightarrow \text { Brand } \\
\text { Personality Appeal }\end{array}$ & 0,2511 & 3,1827 & $\begin{array}{l}\text { Significant direct and } \\
\text { positive path coefficient }\end{array}$ & Yes \\
\hline $\mathrm{H}_{4}$ & $\begin{array}{l}\text { Simplicity } \rightarrow \text { Brand } \\
\text { Personality Appeal }\end{array}$ & $-0,0661$ & 1,1772 & Insignificant & No \\
\hline $\mathrm{H}_{5}$ & $\begin{array}{l}\text { Emotionality } \rightarrow \text { Brand } \\
\text { Personality Appeal }\end{array}$ & 0,0699 & 1,471 & Insignificant & No \\
\hline
\end{tabular}

Source: Own-self processed using SMARTPLS 2.0

Table 12 Summary of the Structural Model: Brand Personality to Attitude via Brand Personality Appeal as Mediating Effect

\begin{tabular}{|c|c|c|c|c|c|c|c|}
\hline $\mathrm{H}$ & & Path a & Path b & Path c & SE & t-value & Supported \\
\hline$\overline{\mathrm{H}_{6}}$ & $\begin{array}{l}\text { Responsibility } \rightarrow \text { Brand Personality } \\
\text { Appeal } \rightarrow \text { Attitude }\end{array}$ & 0,46 & 0,879 & 1,743 & 0,07 & 19,13 & Yes \\
\hline $\mathrm{H}_{7}$ & $\begin{array}{l}\text { Activity } \rightarrow \text { Brand Personality Appeal } \\
\rightarrow \text { Attitude }\end{array}$ & 0,18 & 0,879 & 1,217 & 0,09 & 11,77 & Yes \\
\hline $\mathrm{H}_{8}$ & $\begin{array}{l}\text { Aggressiveness } \rightarrow \text { Brand Personality } \\
\text { Appeal } \rightarrow \text { Attitude }\end{array}$ & 0,25 & 0,879 & 1,349 & 0,08 & 14,11 & Yes \\
\hline $\mathrm{H}_{9}$ & $\begin{array}{l}\text { Simplicity } \rightarrow \text { Brand Personality Appeal } \\
\rightarrow \text { Attitude }\end{array}$ & $-0,07$ & 0,879 & 0,747 & & & No \\
\hline $\mathrm{H}_{10}$ & $\begin{array}{l}\text { Emotionality } \rightarrow \text { Brand Personality } \\
\text { Appeal } \rightarrow \text { Attitude }\end{array}$ & 0,07 & 0,879 & 1,011 & & & No \\
\hline
\end{tabular}

Source: Own-self processed using SMARTPLS 2.0

Table 13 Summary of the Structural Model: Brand Personality to Behavioral Intentions via Brand Personality Appeal as Mediating Effect

\begin{tabular}{|c|c|c|c|c|c|c|c|}
\hline $\mathrm{H}$ & & Path a & Path b & Path c & SE & t-value & Supported \\
\hline $\mathrm{H}_{11}$ & $\begin{array}{l}\text { Responsibility } \rightarrow \text { Brand Personality } \\
\text { Appeal } \rightarrow \text { Behavioral Intentions }\end{array}$ & 0,46 & 0,85 & 1,701 & 0,07 & 18,71 & Yes \\
\hline $\mathrm{H}_{12}$ & $\begin{array}{l}\text { Activity } \rightarrow \text { Brand Personality Appeal } \rightarrow \\
\text { Behavioral Intentions }\end{array}$ & 0,18 & 0,85 & 1,183 & 0,08 & 12,88 & Yes \\
\hline $\mathrm{H}_{13}$ & $\begin{array}{l}\text { Aggressiveness } \rightarrow \text { Brand Personality } \\
\text { Appeal } \rightarrow \text { Behavioral Intentions }\end{array}$ & 0,25 & 0,85 & 1,313 & 0,07 & 15,71 & Yes \\
\hline $\mathrm{H}_{14}$ & $\begin{array}{l}\text { Simplicity } \rightarrow \text { Brand Personality Appeal } \\
\rightarrow \text { Behavioral Intentions }\end{array}$ & $-0,07$ & 0,85 & 0,721 & & & No \\
\hline $\mathrm{H}_{15}$ & $\begin{array}{l}\text { Emotionality } \rightarrow \text { Brand Personality } \\
\text { Appeal } \rightarrow \text { Behavioral Intentions }\end{array}$ & 0,07 & 0,85 & 0,976 & & & No \\
\hline
\end{tabular}




\section{CONCLUSION AND SUGGESTIONS}

This study carried out by developing a model to analyze whether brand personality has an influence to brand personality appeal, plus knowing as if brand personality has a significant impact to attitude and behavioral intentions through brand personality appeal.

After gathering, processing, and analyzing the data, conclusions of the study are Out of fifteen hypotheses which had been proposed, nine hypotheses supported and 6 hypotheses not supported. The result showed three of five dimensions of Brand Personality are impactful directly to Brand Personality Appeal and have an indirect effect to consumer Attitude and consumer Behavioral Intentions. These dimensions are Responsibility, Aggressiveness, and Activity. The highest influencer is Responsibility, then following by Aggressiveness and Activity. The one who should be avoided is simplicity because not only insignificant, it also has a negative influence for GrabBike brand personality appeal.
GrabBike in Indonesia should establish and nurture quality relationships between their brand personality and its appeal for maintain positive consumer's attitude and behavioral intentions. In doing so, the construction for utilizing potential brand personality is crucial. The result would help brand managers to understand the role of brand personality appeal in strengthening brand-consumer attitude and behavioral intentions. Also, brand managers should pay close attention for all those matters in order to have appropriate measures and keep track of their brands' consumers.

Further research need for more deep and specific analysis using multiple mediating effect for each dimension of brand personality appeal, direct influence of brand personality to attitude and behavioral intentions on GrabBike brand for better complete research. Next, the research can try to add more sample size and geographical scope together with another services brand objects for additional perspectives.

\section{REFERENCES:}

Badan Pusat Statistik Indonesia. 2017. Statistik Indonesia (Statistical Yearbook of Indonesia) 2017. Jakarta: Badan Pusat Statistik.

Badan Pusat Statistik Provinsi DKI Jakarta. 2016. Jakarta dalam Angka 2016. Jakarta: BPS Provinsi DKI Jakarta.

Freling, T.H., Crosno, J.L. and Henard, D.H. (2011), "Brand personality appeal: conceptualization and empirical validation", Journal of the Academy of Marketing Science, 39(3), 392-406. http://www.journals.sagepub.com/loi/jam

Gordon, Ross, Nadia, Zainuddin., and Christopher, A. Magee. (2016). "Unlocking the potential of branding in social marketing services: Utilising brand personality and brand personality appeal". Journal of Services Marketing, 30(1), 48-62. http://www.emeraldinsight.com/journal/jsm

Hardjanti, Adiati. 2011. Peran Brand Image, Trust dan Awareness Terhadap Behavioral Intention Melalui Brand Preference, Customer Perceived Value dan Satisfaction. Jurnal Bisnis dan Akuntansi, 13(2).

Lovelock, Chirstopher., Jochen Writz (2011) “Service Marketing People,Technology, Strategy 7th edition”. England: Pearson Education Limited.

Malhotra, Naresh K. 2015. Marketing Research An Applied Orientation Sixth Edition. England: Pearson Education Limited. 
